\title{
Female Entrepreneurship: Evolution, Current Challenges, and Future Prospects
}

\author{
Valdeci Ferreira dos Santos ${ }^{1}$, Greiciele Macedo Morais ${ }^{1}$, Fernanda Ferreira de Araújo Ribeiro ${ }^{1} \&$ Daniel Jardim \\ Pardini $^{1}$ \\ ${ }^{1}$ FUMEC University, Minas Gerais, Brazil \\ Correspondence: Valdeci Ferreira dos Santos, PhD student in Business Administration, FUMEC University, Minas \\ Gerais, Brazil.
}

Received: August 11, 2019

Accepted: September 5, 2019

Online Published: September 8, 2019

doi:10.5430/ijba.v10n5p24

URL: https://doi.org/10.5430/ijba.v10n5p24

\begin{abstract}
The current paper presents reflections on female entrepreneurship through a history of its development, characteristics, gender dichotomy, we also discuss the insertion of women in the business sector in different regional, cultural, economic, and social contexts. The article evaluates an evolution of entrepreneurship since colonial times, and describes it over the last decades, addressing barriers, dynamic potential, possibilities, challenges, and trends. As a methodological approach, we verified the academic literature through database searches, such as Capes, SPELL, EBSCO HOST, and Google Scholar. The abundance of recent studies carried out in different countries made it possible to explain the subject comprehensively. It is clear from the study that since ancient times, women fought for their spaces with many achievements. However, much more remains to be discussed and rethought to value, emerge, and support the development and growth of female entrepreneurship, as In this field remain open challenges to overcome. Both evolution and trends for female entrepreneurship are related to the cultural dimensions of institutional collectivism, gender egalitarianism, social awareness, and women's empowerment, as they shift through family structures and traditions. As an academic contribution this study presents the main context factors and characteristics of female entrepreneurship, discussed in the literature. In practice, the article helps to explain to entrepreneurs and potential entrepreneurs about the challenges that can be overcome through training and qualification, but also presents the barriers imposed by the market that depend on collective actions and government policies, which propose to discuss the culture and gender bias.
\end{abstract}

Keywords: inequality, evolution, genre, tendencies

\section{Introduction}

The role of women in society changed over the last decades, highlighting the increase of their participation in the labor market (ALPERSTEDT; FERREIRA; SERAFIM, 2014), not only as employees but also as employers. Notably, the reach of female entrepreneurship stands out in the strengthening of small and medium enterprises (SILVA; MAINARDES; LASSO, 2016).

Debating female entrepreneurship is relevant to the economy of all nations, as the rise of entrepreneurship strengthens society at its foundations, thus demonstrating the possibility of reducing problems related to barriers imposed by prejudice (ALPERSTEDT; FERREIRA; SERAFIM, 2014).

The growth in rates of female entrepreneurship becomes more influential and robust over time (CANTU CAVADA et al. 2018). Nevertheless, in many countries, there are more male entrepreneurs than female entrepreneurs. Female entrepreneurship faces barriers imposed by society, formal institutions, cultural and economic conditions, which makes it challenging to start or develop a new enterprise.

Understanding the characteristics of female entrepreneurship is relevant to society, as it fosters the debate on gender equality and increasing entrepreneurial capacity in society. Particularly in developing countries, this debate is essential, as women need to proactively find ways to generate income and enter the labor market, enabling progress and the fostering of economic improvements (CANTU CAVADA, et al., 2018). 
This article presents the way female entrepreneurship evolved, its main characteristics, barriers, dynamic potential, possibilities, trends, and challenges, through a review of the available academic literature, concatenated with the potentialities and demands related to the theme.

\section{Methodological Aspects}

The article is exploratory and descriptive since it builds knowledge through the selection and analysis of scientific papers published in journals and indexed in databases based on a specific theme (VIEIRA, 2002; GIL, 2008), in this case, female entrepreneurship.

The methodological approach was to verify the academic literature through database searches (Capes Journal Portal, SPELL, EBSCO HOST and Google Scholar), which selected previous research from authors such as Schumpeter (1984), Hisrich and Peter (2004), and Dolabela (2011), but also privileging the literature published in recent years in national and international journals. The term used for the research was "female entrepreneurship", for which the following results were obtained: Capes journal portal (1,343 peer reviewed and 1,709 online resources), SPELL (39), EBSCO HOST (138 full text results) and Google Scholar (13,200 results). In the research were not used filters other than those already mentioned. The abundance of recent studies, carried out in different contexts, made it possible to perform a comprehensive investigation.

\section{Female Entrepreneurship}

In the following sections, some aspects related to Female Entrepreneurship are presented. This explanation enables the reader to know more about its emergence, evolution, characteristics, challenges, and trends of female entrepreneurship.

\subsection{The Evolution of Female Entrepreneurship}

The notion of entrepreneurship is directly linked to those people who generate or seize opportunities and, from this, develop an organized economic activity, creating value for themselves and society (CARREIRA et al., 2015). Schumpeter (1984) already stated that entrepreneurship drives economic development and growth. Thus it defines the entrepreneurial function with a fundamental role to stimulate economic dynamism, using ideas and technical inventions, supported by the financial framework, transforming these ideas into innovations, whether commercial or technological organizational.

This idea presupposes the definition that entrepreneurship is a value creator for society. The characteristics of female entrepreneurship are researched for their peculiarities and perceived challenges (CARREIRA et al., 2015). Since colonial times, women were subjected to moralism, which tries to subject them to various restrictions. Among these constraints is women's difficulty in holding higher positions within a company, as well as earning a salary equal to that of men in the same position (LAGES, 2005). Women's personality is historically founded on the difference (CRAMER et al., 2012).

In the early twentieth century, women achieved civil and political rights through social struggles provided by their access to education, which meant the beginning of the search for gender equality. In the 1970s, these movements had a positive effect on social institutions, redefining gender division in labor. Since then, the participation of women in the labor market increased, but despite this growth, it remains smaller in relation to men's participation (LAGES, 2005).

In the 1980s, female entrepreneurship began to be highlighted as a research subject. During this period, at least quantitatively, research on female entrepreneurship grew and began to demonstrate the patterns found. This increase occurred, at least in theory, by the growth of female participation in the labor market, not only as an employee but also as an employer and owner of their own business (GOMES et al., 2014).

Gomes et al. (2014) pointed out that in the 80's:

women entrepreneurs were viewed in terms of sexual stereotypes in the process of borrowing at financing institutions and concluded that financial agents had a widespread and prejudiced understanding that women were less likely to succeed compared to women. Since they would not possess the "attributes" necessary to be a true entrepreneur. (GOMES et al., 2014, pág. 323).

Also according to the author, this scenario changed in the following decades, being very relevant the role of liberal feminism that admitted that women were disadvantaged in relation to men, due to discrimination or contingency factors, which deprived them of resources, such as education and business experience. The admission of these questions brought a strong reflection on the theme of social feminism, considering that a large part of society recognized that there were differences between men and women in the labor market. 
However, these differences appeared as a result of a socialization process inherent to the changing societal standards, which was evidenced in different cultural contexts, and in some societies, women obtained more rights than in others. However, it is also relevant to clarify that feminism brought to light the debate on the potentiality of female entrepreneurship, but by itself, it does not justify it (GOMES et al., 2014).

The evolution of female entrepreneurship showed different percentages in each locality, and notably, in some countries it is already balanced (ALPERSTEDT; FERREIRA; SERAFIM, 2014), reaching this balance due to many changes over time. Career et al. (2015) pointed out that the number of female entrepreneurs grew three times faster compared to the growth rate of US global companies, according to that country's Businesswomen Research Center. However, in Brazil, data from the 2012 report published by Global Entrepreneurship Monitor (GEM) indicated that the initial female entrepreneurship rate is $14.7 \%$ of the adult population, which places Brazil in 15th position among 67 surveyed countries.

Other relevant data showed a ratio of 1.1 to the number of entrepreneurs in Brazil. In this sense, the relationship between entrepreneurial men and women is possibly close to equality, which suggests that Brazil is surpassed only by nine countries. The female entrepreneurship rate in the South region exceeded the Brazilian average, reaching a total of $15.3 \%$, with a male/female ratio of 1 , an even higher proportion than the rest of Brazil (GLOBAL ENTREPRENEURSHIP MONITOR, 2012).

The ratio between men and women tends to vary from country to country, also highlighting the fact that the percentage of female entrepreneurship differs by issues related to the social structure, culture, customs, and technological structure of each country and evolves differently (ALPERSTEDT; FERREIRA; SERAFIM, 2014). Therefore, global leaders need to create cultures for equality, becoming a value for all, conveying the vision of gender-based non-discrimination (UN, 2016).

\subsection{Characteristics of Female Entrepreneurship in Different Contexts}

Scholars in various parts of the world are busy contributing to the literature on the characteristics of entrepreneurs and their interaction with various contexts and lines of business.

The entrepreneurial way of being, for Dolabela (2011), is related to worldview, protagonism, lifestyle, positioning in the face of ambiguity and uncertainty environments, skills and capacities for inner change and in the context in which subjects are inserted, as well as innovative aptitude and self-realization.

By analyzing the characteristics of Brazilian entrepreneurs, Silva, Lasso, and Mainardes (2016) found that most of them are between 30 and 49 years old, are married and completed higher education. Usually, they run family-owned businesses, although there are also a considerable number of non-family-owned businesses run by female entrepreneurs. For them, the role of the family is fundamental to the management of the enterprise, especially the spouse.

The same research highlighted that Brazilian women are daring more, and despite facing difficulties to get financing for their business, are starting businesses alone. To do this, they most often use their resources. The same research also observed the importance of the experiences acquired in previous works for the management of the projects. However, most female entrepreneurs recognized that they lack sufficient marketing, finance, and technology skills and need further improvement. Female entrepreneurs also emphasized that the organizations run by them survived longer than other businesses (SILVA; LASSO; MAINARDES, 2016).

Similar research was developed by (CARREIRA et al., 2015) with twelve entrepreneurs, presenting their profile, personal characteristics, how was the development of the enterprise itself, as well as its current and future vision about their businesses located in the states of São Paulo, Santa Catarina, and Paraná. The study identified that the entrepreneurs had the following characteristics: persistence and determination based on courage and confidence in the work they perform; research-based market and opportunity insight; intuition and perception of opportunities; perseverance in their goals; They regard family and faith as allies, supporters, and foundations.

The strengths pointed out were: setting and meeting goals, planning, meeting deadlines, initiatives, attitudes, forming and maintaining a robust network of contacts. When it comes to the risk factor, entrepreneurs preferred to act safely and moderately. For them, to be successful in the business is to have their brands recognized and requested, large numbers of customers, satisfied, and loyal (CARREIRA et al., 2015).

In Spain, Nogueira et al. (2015) explored the influence of environmental factors on entrepreneurial activity in the country context. To achieve that, they developed a longitudinal analysis for the period 2003-2010, using data from the Global Entrepreneurship Monitor and the National Institute of Statistics of Spain. 
Their main findings showed that factors such as education, family background, and income level differences played no significant influence on female entrepreneurship. On the other hand, the research pointed out that aspects such as social recognition of entrepreneurship, career networks, and women's networks seemed to be more relevant to the creation of companies by women (NOGUEIRA et al., 2015).

In order to identify the factors influencing female entrepreneurial activity in the Iranian context, Khyareh (2018) developed a survey using data from the Global Entrepreneurship Monitor from 2010 to 2015. Their findings revealed that female entrepreneurship in Iran did not relate to a high level of formal education. One possible explanation for this conclusion is that women with higher levels of formal education are more likely to enter the labor market, while women with lower levels of formal education are less likely to be employed and are more likely to become entrepreneurs for women.

The same study also pointed out that Iranian entrepreneurs are small business enthusiasts and tried to finance their businesses with their own money, from their friends or family. One explanation for this trend is that women are more risk-averse than men, and this is one of the reasons why Iranian women prefer small businesses with a smaller amount of seed money.

The purpose of joining Iranian female entrepreneurship is not to make money but to become independent and have flexibility. Women entrepreneurship is related to entrepreneurial skills and women entrepreneur networks, with experience, skills, and knowledge not significantly related to entrepreneurship out of necessity. Needy entrepreneurs are often inexperienced, low-income, and low-educated (KHYAREH, 2018).

To discover and determine the problems and obstacles experienced by women entrepreneurs, as well as the reasons that motivate them to choose a career in the field of entrepreneurship in the region of Albania, Macedonia, and Kosovo (ALMAKOS), Ramadani, Hisrich, and Gerguri-Rashiti (2015) conducted a survey of 24 businesswomen from Albania, 32 from Macedonia, and 18 from Kosovo.

Their results study showed that the freedom to make business decisions is the main motivating factor for female entrepreneurship in ALMAKOS countries, followed by the possibility of making money and profit, as well as the desire to achieve significant career achievements. To achieve their goals, women need to overcome some obstacles.

The main barriers faced by these entrepreneurs are related to the difficulties in balancing family obligations with work commitments. Keeping in mind that they devote most of their available time to their business, they can also face problems fulfilling their responsibilities as wives and mothers. To overcome these problems, women need to possess various qualities and skills. Successful businesses require education, knowledge, and skills, as well as a commitment to be proactive rather than reactive. Experience, persistence, perseverance, and self-confidence are also considered essential characteristics for successful business development (RAMADANI; HISRICH; GERGURI-RASHITI, 2015).

Cavada, Bobek, and Macek (2017) developed a study on the factors that motivated women entrepreneurs to start their businesses in Mexico. They concluded that the development of female entrepreneurship is influenced by different factors, including personal characteristics of female entrepreneurs, social, and economic factors. Due to their traditionally conservative attitude, adverse risk tendency, and lack of cooperation from family members, etc., Mexican entrepreneurs are sometimes deterred from starting businesses.

However, research has proven that the lack of other economic prospects and unemployment encourage women to start their businesses. The growing number of non-governmental institutions that are generating opportunities for women during the conception phase of the entrepreneurship process is also a factor driving female entrepreneurship in Mexico (CAVADA; BOBEK; MACEK, 2017).

In Kenya, the study by Lock; Lawton Smith (2015) showed that Kenyan women are leaving stable jobs in the formal sector to start their businesses, a more favorable work environment. The availability of microfinance empowers most women and develop their role as businesswoman, and in many respects are not deterred or retained by their dual role as businesswoman and keeper of the household.

The evidence in this study suggests that it is the need that drives women into entrepreneurship, but it is the attracting factors (independence, challenge, initiative and ideas) that keep them motivated and aiming for success. However, the evidence suggests that microfinance is, in some cases, purely an instrument of poverty self-relief.

Besides, education plays a crucial role in the success of women entrepreneurs. While many may not have attained secondary school qualifications, there is room for an intermediate level of business training that would not only benefit women and their businesses, but also the community around them. The perceived success of Kenyan 
entrepreneurs is that they can support themselves and their families and, in many cases, support others in their community. This is another positive impact of microfinance and female entrepreneurship (LOCK; LAWTON SMITH, 2015).

The lack of desire to expand their business by most interviewees can be explained as an unintended consequence of lending. Their business lack sustainability. An alternative explanation is that the lack of knowledge and education about how to develop the business prevents them from expanding them (LOCK; LAWTON SMITH, 2015).

Considering that $46 \%$ of Kenyans currently live below the poverty line (UNICEF 2018), it is clear that the living standards of study participants are notably higher. Most entrepreneurs lived in homes with access to water and electricity, in secure buildings, they were able to provide for their families (LOCK; LAWTON SMITH, 2015).

By analyzing these studies, we observed that the characteristics, challenges, and trends of female entrepreneurship are directly related to the context in which women are inserted. Factors such as culture, customs, technological and economic development, public policy, among others, define both women's ability and decision to create and develop their own business.

\subsection{Female Versus Male Entrepreneurship}

The insertion of women in spaces for business creation and development intensified in the last years (HISRICH; PETER, 2004). Thus, studies on the characteristics of female entrepreneurs raised the interest of researchers in the area, revealing that women have some characteristics common to entrepreneurs. However, women's motivations differ from other entrepreneurs, such as the pursuit of flexibility to better manage work-life balance (THÉBAUD, 2015).

Entrepreneurs' motivation is manifested in the accomplishment and pursuit of making business happen. They value personal independence; self-image and performance status are not so important, but they value and seek job satisfaction through occupying command spaces. The most common motivation for beginning as an entrepreneur is the desire to achieve independence (HISRICH; PETER, 2004).

For the authors, the male entrepreneurial decision, or starting point, is often dissatisfaction with current employment, resignation, college projects, current job learning, need for progress, and opportunity to acquire. For females, not unlike, the starting point is linked to job dissatisfaction or frustration; need or interest, recognition of opportunity in the area, the pursuit of personal change.

The funds used by entrepreneurs most often involve personal assets and savings, investors, bank financing, loans from friends and family. Entrepreneurs have a preference for funds from savings and personal assets, as well as personal loans (HISRICH; PETER, 2004). Thébaud (2015) adds that gender roles can also limit women entrepreneurs' access to critical resources such as human, financial, and social capital.

Thébaud (2015) reported that a significant challenge is access to resources. Female entrepreneurs generally have less capital and are more dependent on equity than men. The author highlights the existence of an extensive body of research that points to gender-based differences in terms of access to credit, such as collateral requirements and interest rates, although credit institutions control sector and size-based characteristics of the business.

Regarding professional history, (HISRICH; PETER, 2004) highlighted a few differences between entrepreneurs. They usually have experience in the field of work, are recognized or highly skilled specialists in the field, and have skills in many of the business roles. They already have experience in the business area, experience in middle management or management. Contrary to one of the challenges highlighted by Thébaud (2015), women entrepreneurs generally have less self-employment experience and, as a result, have less developed management skills, as well as smaller business networks on average.

Other relevant factors are personality traits that the entrepreneur expresses through persuasion and opinions, goal orientation, being idealistic and innovative, high level of self-confidence, energetic and enthusiastic, seeking to be his boss. Entrepreneurs have a tolerant and flexible personality, also goal-oriented, realistic and creative, medium level of confidence, energetic and enthusiastic, and have skills to deal with the social and economic environment (HISRICH; PETER, 2004).

The insertion into the business world for men occurs between 25 and 35 years, commonly with higher education in administration or technical area. However, women start between their 35 and 45 years and also tend to have higher education. They are supported at this stage by friends, well-known professionals, business associates, spouses, families, business associations, among others (HISRICH; PETER, 2004). 
As for the types of business, differences also occurred. Male entrepreneurs look to the industry or construction sectors. Female entrepreneurs focus on the area of services such as education, consulting, and public relations (HISRICH; PETER, 2004). Although there are some differences between the drivers and determinants of female entrepreneurship and male entrepreneurship, Thébaud (2015) highlights that women-owned businesses are as sustainable as those operated by men. Business survival rates for female entrepreneurs are roughly equal to male-owned businesses in some countries.

In addition to the characteristics already pointed out, culture and social attitudes also play an essential role in shaping women's entrepreneurship. Traditional gender roles can lead women to self-limit their entrepreneurship to "feminized" activities, professions, sectors, and fields of business. Noting further that market failures is another factor that impacts entrepreneurship and makes it even harder for women to start and succeed in this field (THÉBAUD, 2015).

From this perspective, in his research, Thébaud (2015) sought to understand the antecedents of the challenges that lead to the under-representation of women in entrepreneurship, a form of gender inequality. It also seeks, by the beliefs of status and spirit of capitalism, to understand how forms of gender inequality are reproduced in modern societies.

The author concluded that gender status beliefs are salient in the context of entrepreneurship and are responsible, at least in part, for the disadvantages that women entrepreneurs face. Status beliefs lead most people to doubt women's entrepreneurship, even subtly, women may be discouraged from pursuing entrepreneurship.

For Thébaud (2015), although women, being innovative, may be able to mitigate their vulnerability strategically, this would not substantially challenge the gendered beliefs they are conditioned on and inequality at the macro level. Thus, the author asserts that the barrier of inequality in entrepreneurship should be understood as a problem rooted in the social and economic institutions that support gender inequality in the labor market more broadly.

\subsection{Challenges and Trends of Female Entrepreneurship}

Despite the significant advancement in the development of female entrepreneurship, women still face some challenges to enter the job market, achieve pay equity, start and develop their own business. These challenges are influenced by the various roles they played in balancing business and home activities (GIMENEZ; FERREIRA; RAMOS, 2017), and the poor support they receive from other family members, especially from the spouse (SILVA; LASSO; MAINARDES, 2016).

This factor feeds the discussion of one of the biggest difficulties for the possibility of female entrepreneurship, which would be the challenge of performing their multiple daily tasks, traditionally performed by women in society, related to the care of family and residence, balancing with their potential creative entrepreneur (GIMENEZ, FERREIRA; RAMOS, 2017; ALPERSTEDT; FERREIRA; SERAFIM, 2014).

Although women nowadays show persistence, determination, courage, confidence in their work and market vision (CARREIRA et al., 2015), one of the challenges faced is the need for improvement in the areas of marketing, finance, technology and information technology (SILVA; LASSO; MINARDES, 2016) as well as a higher insertion in the field of science and technology (HALABISK, 2017), so that they can better insert and manage their business.

Difficult access to finance is another important challenge faced by female entrepreneurship (SILVA; LASSO; MAINARDES, 2016). Gender issues also affect and limit women's access to financial, human, or social resources (THÉBAUD, 2015). This challenge relates to the prejudice that women entrepreneurs may not succeed in transforming resources into results compared to men (GOMES et al., 2014). Also, they highlight (CANTU CAVADA et al., 2018) the lack of social credibility and acceptance of women, which causes fear and vulnerability to criticism and social pressures in society.

Still, in the context of the challenges faced, women's lack of self-esteem and self-confidence diminishes their entrepreneurial ability, which may influence their low-risk tolerance for starting a new business. Thus, in general terms, women are comparatively more risk-averse than men (CANTU CAVADA et al., 2018).

Given these challenges, we understood that the opportunities generated during the business conception phase demonstrate a relationship with the cultural dimensions of institutional collectivism, gender egalitarianism, social awareness, and women's empowerment. On the other hand, the variables related to institutional collectivism are based on the fact that important and significant opportunities for entrepreneurs must be developed by government agencies and non-governmental institutions (CANTU CAVADA et al., 2018). 
For (CAVADA; BOBEK; MACEK, 2017), society is already facing a major revolution towards the strengthening of female entrepreneurship, permeated by the change in family structures and traditions. Women currently have more opportunities to develop as entrepreneurs.

According to Gimenez, Ferreira, and Ramos (2017), there are some highlights for female entrepreneurship trends, among them women's perception in the exercise of their entrepreneurial role, analyzing their importance, and reflecting on the difficulties faced and results obtained. Another trend, specifically, regarding the financial acquisition of resources, would be the option of women for bank financing or formal loans, stimulated by access policies (CANTU CAVADA et al., 2018). Entrepreneurs tend to pursue business more reflexively, analyzing the risks and possibilities of earnings, taking fewer risks, and seeking safer activities.

An important global trend is the growth and equalization of female and male entrepreneurship (ALPERSTEDT; FERREIRA; SERAFIM, 2014), without, however, eliminating all differences between entrepreneurial men and women, but seeking to remove negative institutional influences that affect the intention, motivation, and access to female entrepreneurship (HALABISK, 2017).

\section{Final Considerations}

The current article sought, through a literature review, to present the evolution of female entrepreneurship. We described female entrepreneurship over the last decades, its characteristic barriers, its dynamic potential, its possibilities, trends, and nowadays challenges, concatenated with the potentialities and demands related to the theme in different regions, cultures and economic contexts of the world.

Women have latent potential in entrepreneurship. Since ancient times, colonial times, they fought for their spaces in the job market. Later on, during the 70's and 80's, their insertion as employers and owners of their businesses. Since then, they acquired support, achieved recognition, and grew their presence in the market, whether work or business, has become promising. However, much remains to be discussed and rethinking to value, emerge, and support the development and growth of female entrepreneurship.

It is noticed that the characteristics of female entrepreneurship directly relates to the context in which women are inserted. In these contexts, factors such as culture, customs, technological and economic development, public policy, among others, define both women's ability and decision to create and develop their own business. However, some characteristics are similar in different contexts, such as the preference for small businesses, venture capital financing, risk aversion, acting safely and moderately, start their business older than men. When we compare the characteristics of entrepreneurs, we can see significant differences in motivation and achievement, starting point, sources of funds, professional background, personality, background, support groups and types of business (HISRICH; PETER, 2004).

Despite the significant advancement in the development of female entrepreneurship, women still face some challenges, such as the difficulty of reconciling their professional life with the home tasks they traditionally perform; the need for improvement in the areas of marketing, finance and technology, information technology, and higher insertion in the field of science and technology; difficulty in accessing finance; lack of self-esteem and self-confidence. Gender issues also affect and limit women's access to resources, whether financial, human, or social. Moreover, the lack of social credibility and acceptance of women causes fear and vulnerability to social criticism and pressure from society.

The evolution and trends for female entrepreneurship demonstrate a relationship with the cultural dimensions of institutional collectivism, gender egalitarianism, social awareness, and women's empowerment. Consequently, both governmental and non-governmental institutions should develop actions to support the development of female entrepreneurship. In this sense, the strengthening of female entrepreneurship involves the change in family structures and traditions.

The development of female entrepreneurship tends to the woman's perception in the exercise of her entrepreneurial role, analyzing its importance, and reflecting on the difficulties faced and results obtained. Another trend, specifically, regarding the financial acquisition of resources, would be the option of women for bank financing or formal loans, stimulated by access policies (CANTU CAVADA et al., 2018). Considering their characteristics, entrepreneurs should continue the tendency to pursue business more reflectively, analyzing the risks and possibilities of gains, taking fewer risks, and seeking safer activities.

An important global trend is the growth and equalization of female and male entrepreneurship (ALPERSTEDT; FERREIRA; SERAFIM, 2014), without, however, eliminating all differences between entrepreneurial men and women, but seeking to remove negative institutional influences that affect the intention, motivation, and access of female entrepreneurship (HALABISK, 2017). Thus, another important and necessary trend towards reducing gender 
inequality and rebalancing include attracting more women investors and consultants as part of the traditional ones: venture capital, networking, the formation of women's capital funds, directing investments towards strengthening female entrepreneurship (HALABISK, 2017).

In this context of female entrepreneurship, therefore, it is understood the importance of more support of public policies in encouraging the formation of women, venture capital investments, corresponding funds for investments in companies owned or led by women, either at an early stage or expanding.

This study contributes to the literature by presenting a theoretical review on female entrepreneurship, addressing its development, characteristics, challenges and trends, enabling academics to gain insight into the main aspects surrounding female entrepreneurship. The practical contribution of the study is to present these aspects to women entrepreneurs and potential women entrepreneurs, in order to inform them about the potentialities and limitations of female entrepreneurship, especially regarding the knowledge of the barriers that are related to the development of their skills entrepreneurship and barriers that are related to extrinsic factors, such as government policies, culture, prejudice, gender issues and others. However, this article has as limitation the little depth of the theme, suggesting for further work researches that approach the theme in more depth, in different regions to obtain information about the influence of the environment, culture, economy, religion and other aspects involving female entrepreneurship.

\section{References}

Alperstedt, G. D., Ferreira, J. B., \& Serafim, M. C. (2014). Empreendedorismo feminino: dificuldades relatadas em histórias de vida. Revista de Ciências da Administração, 221-234. https://doi.org/10.5007/2175-8077.2014v16n40p221

Cantú, C. M., et al.. (2018). Cultural foundations of female entrepreneurship in Mexico: challenges and opportunities. Nase gospodarstvo/Our economy, 64(1), 28-40. https://doi.org/10.2478/ngoe-2018-0004

Carreira, da S. S., et al.. (2015). Empreendedorismo feminino: um estudo fenomenológico. Navus-Revista de Gestão e Tecnologia, 5(2).

Cavada, M. C., Bobek, V., \& Maček, A. (2017). Motivation factors for female entrepreneurship in Mexico. Entrepreneurial Business and Economics Review, 5(3), 133-148. https://doi.org/10.15678/EBER.2017.050307

Cramer, L., et al.. (2012). Representações femininas da ação empreendedora: uma análise da trajetória das mulheres no mundo dos negócios. Regepe-Revista de Empreendedorismo e Gestão de Pequenas Empresas, 1(1), 53-71. https://doi.org/10.14211/regepe.v1i1.14

Dolabela, F. (2011). Oficina do empreendedor. Sextante.

GIL, A. C. (2008). Métodos e Técnicas de Pesquisa Social (6th ed.) São Paulo: Atlas.

Gimenez, F. A. P., Ferreira, J. M., \& Ramos, S. C. (2017). Empreendedorismo Feminino no Brasil: Gênese e Formação de um Campo de Pesquisa. Revista de Empreendedorismo e Gestão de Pequenas Empresas, 6(1), 40-74. https://doi.org/10.14211/regepe.v6i1.450

Gomes, A. F., et al.. (2014). Empreendedorismo Feminino como Sujeito de Pesquisa. Revista Brasileira de Gestão de Negócios, 16(51). https://doi.org/10.7819/rbgn.v16i51.1508

Halabisky, D. (2017). International Trade Forum, 4, 10-11.

Hisrich, R. D., \& Peter, M. P. (2004). Empreendedorismo. Porto Alegre: Bookman.

Khyareh, M. M., et al.. (2018). Determinants Of Female Entrepreneurship In Iran: An Institutional Approach. Economic Annals, 63(216), 111-130. https://doi.org/10.2298/EKA1816111K

Lages, S., \& Regina, C. (2005). Desafios do empreendedorismo feminino: uma reflexão sobre as dificuldades das mulheres pobres na condução de projetos geradores de renda. Revista Estação Científica.

Lock, R., Lawton, S., \& Helen. (2016). The impact of female entrepreneurship on economic growth in Kenya. International Journal of Gender and Entrepreneurship, 8(1), 90-96. https://doi.org/10.1108/IJGE-11-2015-0040

Monitor. (2012). Global Entrepreneurship, Empreendedorismo no Brasil. Relatório Executivo.

Mulheres, O. N. U. (2016). Princípios de empoderamento das mulheres. Entidade das Nações Unidas para a Igualdade de Gênero e o Empoderamento das Mulheres. 
Noguera, M., et al.. (2015). Determinants of female entrepreneurship in Spain: an institutional approach. Computational and Mathematical Organization Theory, 21(4), 341-355. https://doi.org/10.1007/s10588-015-9186-9

Ramadani, V., Hisrich, R, D., \& Gërguri-Rashiti, S. (2015). Female entrepreneurs in transition economies: Insights from Albania, Macedonia and Kosovo. World Review of Entrepreneurship, Management and Sustainable Development, 11(4), 391-413. https://doi.org/10.1504/WREMSD.2015.072066

Schumpeter, J. A. (1984). Capitalismo, Socialismo e Democracia. Rio de Janeiro: Zahar.

Silva, M. S. da., Lasso, S. V., \& Mainardes, E. W. (2016). Características Do Empreendedorismo Feminino No Brasil. Revista Gestão e Desenvolvimento, 13(2), 150-167.

Thébaud, S. (2015). Status Beliefs and the Spirit of Capitalism: Accounting for Gender Biases in Entrepreneurship and Innovation. Social Forces, 94(1), 61-86. https://doi.org/10.1093/sf/sov042

Unicef. (2018). Kenya Overview. Retrived August 7, 2018, from http://www.unicef.org/kenya/overview_4616.html

Vieira, V. A. (2002). As tipologias, variações e características da pesquisa de marketing. Revista da FAE, Curitiba, $5(1), 61-70$. 